\title{
Water Extract Influence of Stachytarpheta jamaicensis (L.) Vahl Leaves to Prevent Psoriasis Severity in Animal Model
}

\author{
Encep Abdurahman, Nengdiana Permana, Grace S. Mardiana, Afifah B. Sutjiatmo, \\ Anna Choirunnisa, Suci N. Vikasari* \\ Program Studi Sarjana Farmasi, Fakultas Farmasi, Universitas Jenderal Achmad Yani, Jl. Terusan Jenderal Sudirman \\ PO BOX 148, Cimahi, Indonesia
}

Submitted 02 November 2021; Revised 06 December 2021; Accepted 06 December 2021; Published 30 December 2021 *Corresponding author: suci.vikasari@lecture.unjani.ac.id

\begin{abstract}
Psoriasis is an autoimmune disease that is characterized by the appearance of lesions on the skin. The current treatment aims to control the symptoms. The efficacy of Stachytarpheta jamaicensis (L.) Vahl's for autoimmune rheumatoid arthritis and systemic lupus erythematosus has been tested in animal models. The aim of this research was to evaluate the effect of the water extract of $S$. jamaicensis leaves on psoriasis model animal (male Balb/c mice) induced topically by imiquimod. The water extract of $S$. jamaicensis leaves is made by boiling. The animal was divided into groups: normal, control, methotrexate $0.2 \mathrm{mg} / \mathrm{kgBW}$, the extract (doses 25,50 and $100 \mathrm{mg} / \mathrm{kgBW}$ ). The measured parameters were the Psoriasis Area and Severity Index (PASI) score and skin histopathology. The results showed that all doses of the extract could reduce the PASI score when compared to the control group. Histological results showed that there was a decrease in keratin growth in test animals that were given the extract. Extracts at doses of 25 and $50 \mathrm{mg} / \mathrm{kgBW}$ can reduce the thickening of keratin in the epidermis of the back and ears. It can be concluded that the water extract of $S$. jamaicensis leaf has the most effective activity to prevent psoriasis recurrence in the dose range of 25 and $50 \mathrm{mg} / \mathrm{kgBW}$.
\end{abstract}

Keywords: Psoriasis, Stachytarpheta jamaicensis leaf water extract, PASI, keratin, imiquimod

\section{Efek Ekstrak Air Daun Pecut Kuda (Stachytarpheta jamaicensis (L.) Vahl) untuk Mencegah Keparahan pada Model Hewan Psoriasis}

\begin{abstract}
Abstrak
Psoriasis merupakan penyakit autoimun yang ditandai dengan timbulnya lesi pada kulit. Pengobatan yang dilakukan saat ini bertujuan untuk mengontrol gejala yang timbul. Pecut kuda (Stachytarpheta jamaicensis (L.) Vahl) telah diuji khasiatnya pada model hewan autoimun rheumatoid arthritis dan lupus eritematosus sistemik. Penelitian ini bertujuan untuk mengevaluasi pengaruh ekstrak air daun pecut kuda terhadap hewan model psoriasis (mencit Balb/c jantan) yang diinduksi imiquimod secara topical. Ekstrak air daun pecut kuda dibuat dengan cara perebusan. Kelompok uji terdiri dari: kontrol, pembanding Metotreksat 0,2 mg/kg BB, ekstrak air daun pecut kuda (dosis 25, 50 dan $100 \mathrm{mg} / \mathrm{kgBB}$ ). Parameter yang diukur adalah skor Psoriasis Area and Severity Index (PASI) dan histopatologi kulit. Hasil menunjukan bahwa ekstrak air daun pecut kuda pada semua dosis dapat menurunkan nilai PASI jika dibandingkan kelompok kontrol. Hasil histologi menunjukkan bahwa terjadi penurunan pertumbuhan keratin pada hewan uji yang diberi ekstrak air daun pecut kuda. Ekstrak pada dosis 25 dan $50 \mathrm{mg} / \mathrm{kgBB}$ dapat menurunkan penebalan keratin pada epidermis punggung dan telinga. Dapat disimpulkan bahwa ekstrak air daun pecut kuda memiliki aktivitas untuk mencegah kekambuhan psoriasis yang paling efektif berada pada rentang dosis 25 dan $50 \mathrm{mg} / \mathrm{kgBB}$.
\end{abstract}

Kata Kunci: Psoriasis, ekstrak air daun pecut kuda (Stachytarpheta jamaicensis), PASI, keratin, imiquimod 


\section{Pendahuluan}

Psoriasis merupakan penyakit kulit kronis dan tidak menular namun menyebabkan rasa sakit, kerusakan dan kecacatan pada kulit yang belum bisa disembuhkan serta dapat mengakibatkan penurunan terhadap kualitas hidup pasien. Psoriasis dapat digolongkan sebagai penyakit autoimun yang ditandai dengan timbulnya lesi pada kulit. Lesi kulit yang muncul dapat mengakibatkan rasa gatal, eritema, pembengkakan, rasa perih, nyeri dan penampilan kulit yang buruk sehingga penyakit ini dapat mengakibatkan timbulnya gangguan psikologis seperti timbulnya depresi bahkan adanya keinginan untuk bunuh diri. Psoriasis dapat terjadi pada semua usia baik pada laki-laki maupun perempuan. Prevalensi psoriasis juga di beberapa negara di Eropa, Amerika, Australia dan negara China dilaporkan berkisar antara $0,09 \%$ hingga $11,4 \%$ yang membuat psoriasis menjadi osteoarthritis (OA); suatu penyakit yang serius. ${ }^{1}$

Penyakit ini juga telah dilaporkan dapat menyebabkan penyakit serius lainnya seperti sindrom metabolik, obesitas, diabetes mellitus, dislipidemia, hipertensi dan stres mental. ${ }^{2}$ Telah diketahui bahwa variasi klinis terbanyak kasus psoriasis adalah psoriasis vulgaris yang menyerang kulit yaitu sebesar $90 \% .^{3}$ Karena penyebab psoriasis belum diketahui maka pengobatan dilakukan seumur hidup untuk mengontrol gejala yang timbul. Pengobatan dapat dilakukan dengan tiga cara yaitu terapi topikal, fototerapi dan terapi sistemik. Selama pengobatan juga perlu dilakukan pemantauan terhadap penyakit serius lainnya. ${ }^{1}$

Pengobatan untuk psoriasis dalam jangka waktu yang lama membutuhkan biaya yang sangat mahal, dengan tantangan penderita tidak dapat melakukan pekerjaan dengan baik. Hal tersebut menjadi suatu hambatan dalam perawatan penyakit psoriasis. Selain itu pengobatan dengan obat-obatan seperti kortikosteroid juga dapat memberikan efek samping yang cukup merugikan ${ }^{1}$, sehingga perlu dilakukan penelitian terhadap perawatan baru untuk penderita psoriasis yang lebih terjangkau, efektif, dan aman dalam pengobatan jangka panjang dengan pengobatan menggunakan obat tradisional. Pengobatan tradisional telah terbukti dapat digunakan untuk menekan tingkat keparahan penyakit psoriasis dengan biaya yang lebih terjangkau dan reaksi merugikan yang lebih sedikit jika dibandingkan dengan obat kimia. Namun pengobatan tradisional yang diketahui saat ini berbasis pengobatan Tiongkok yang masih sangat terbatas dan perlu dilakukan eksplorasi lebih lanjut untuk dapat menekan biaya pengobatan dalam jangka panjang. ${ }^{4}$ Maka dilakukan eksplorasi dari tanaman lain yang lebih terjangkau dari pengobatan tradisional Tiongkok. Salah satu tanaman yang diduga berpotensi untuk pengobatan psoriasis adalah daun pecut kuda.

Tanaman pecut kuda (Stachytarpheta jamaicensis (L) Vahl) merupakan tanaman daun yang tumbuh liar dan mudah dijumpai sehingga tidak memerlukan biaya perawatan yang khusus5. Tanaman ini telah banyak digunakan untuk pengobatan tradisional salah satunya dapat mengobati penyakit autoimun seperti rheumatoid arthritis. Aktivitas biologis dari pecut kuda dihasilkan oleh kandungan metabolit sekunder seperti alkaloid, flavonoid, fenol, steroid, dan terpenoid. ${ }^{6}$ Ekstrak air herba pecut kuda juga telah terbukti dapat digunakan untuk pengobatan penyakit lupus eritematosus. ${ }^{7}$ Dilihat dari aktivitas tanaman pecut kuda yang dapat digunakan untuk pengobatan penyakit autoimun, maka dari itu, perlu dilakukan penelitian lebih lanjut terhadap efek penggunaan ekstrak air daun pecut kuda (Stachytarpheta jamaicensis (L) Vahl) untuk mencegah keparahan psoriasis.

\section{Metode}

2.1. Alat

Alat yang digunakan pada penelitian ini adalah termometer, penangas air (Lab Companion), timbangan analitik (Shimadzu), orbital shaker (IKA), tanur (Thermolyne), spuit dan peralatan standar yang tersedia di laboratorium.

\subsection{Bahan}

Bahan kimia yang digunakan untuk pemeriksaan karakteristik simplisia, reagen 
penapisan fitokimia, tanaman pecut kuda (Stachytarpheta jamaicensis (L.) Vahl), air suling (Amidis), krim imiquimod (salep Aldara, 3M Pharmaceuticals), metotreksat tablet (Rheu-trex), CMC Natrium, buffer formalin $\mathrm{pH}$ neutral.

\subsection{Hewan Penelitian}

Hewan yang digunakan adalah mencit Balb/c jantan usia 8-11 minggu bobot badan 20-30 gram dari PT. Biofarma, Bandung. Hewan ditempatkan di dalam ruangan suhu $\pm 25^{\circ} \mathrm{C}$ pada kandang yang sesuai. Penerangan di tempat penyimpanan hewan uji sekitar 12 jam siang dan 12 jam malam. Hewan diaklimatisasi selama satu minggu di lingkungan laboratorium Fakultas Farmasi, Universitas Jenderal Achmad Yani, diberi pakan hewan babi (P551) dan minum air suling (Amidis) ad libitum.

\subsection{Metode}

\subsubsection{Penyiapan Bahan dan Determinasi}

Daun Pecut Kuda diperoleh dari daerah Batujajar, Bandung Barat dan di determinasi di Laboratorium Taksonomi Tumbuhan Jurusan Biologi FMIPA Universitas Padjajaran. Selanjutnya, daun pecut kuda dibuat simplisia dengan cara dikering-anginkan.

\subsubsection{Penentuan Karakterisasi Simplisia}

Penentuan karakteristik simplisia dilakukan berdasarkan pedoman Farmakope Herbal Indonesia untuk menentukan mutu simplisia, meliputi pemeriksaan makroskopis, kadar air, kadar abu total, kadar abu tidak larut asam, kadar sari larut air dan larut etanol ${ }^{8}$ serta kadar abu larut air. ${ }^{9}$

\subsubsection{Prosedur Ekstraksi}

Ekstraksi dilakukan dengan cara merebus 100 gram simplisia dalam $500 \mathrm{~mL}$ air suling selama 30 menit dihitung ketika air berada pada suhu $95-98^{\circ} \mathrm{C}$. Kemudian disaring menggunakan kertas saring dan filtrat ditampung di dalam wadah, dilakukan pengulangan ekstraksi sebanyak 2 kali. Filtrat total yang didapatkan diuapkan diatas penangas air suhu $60^{\circ} \mathrm{C}$ hingga didapatkan ekstrak kental. Ekstrak kental kemudian dipanaskan di dalam oven pada suhu $60^{\circ} \mathrm{C}$ sampai terbentuk ekstrak kering.

\subsubsection{Prosedur Pengujian}

Hewan uji dibagi secara acak menjadi 6 kelompok dengan masing-masing kelompok sebanyak 4 ekor, yaitu normal, kontrol, pembanding metotreksat $0,2 \mathrm{mg} / \mathrm{kgBB}$, ekstrak air daun pecut kuda dosis 25, 50 dan $100 \mathrm{mg} / \mathrm{kgBB}$. Hewan uji dipuasakan terlebih dahulu dan bagian punggung dibersihkan dari bulu hingga terlihat bagian epidermis kulit mencit, lalu dibersihkan dengan alkohol $70 \%$. Punggung hewan uji ditandai daerah dengan luas $6 \mathrm{~cm}^{2}$ untuk kemudian bagian epidermis kulit diinduksi secara topikal dengan 62,5 mg salep Aldara dan bagian telinga kanan dengan $20 \mathrm{mg}$ salep Aldara selama 15 hari. Bersamaan dengan induksi, pada hari ke-7 hingga ke-15, semua kelompok kecuali kelompok normal diberikan sediaan per oral sehari sekali. Parameter yang diukur adalah nilai Psoriasis Area and Severity Index (PASI) dan histopatologi kulit punggung dan telinga kanan. Penentuan skor keparahan PASI ditentukan dengan pengamatan visual yang dilakukan oleh tiga orang pengamat terhadap pertumbuhan plak, kemerahan pada kulit punggung dan kemerahan pada telinga. Setiap parameter diberi skor antara 0 hingga $4(0=$ tidak ada, $1=$ sedikit, $2=$ sedang, 3 = parah, 4 = sangat parah). Nilai PASI diperoleh dengan skor kumulatif dari 0 sampai 12. Histopatologi kulit punggung dan telinga dilakukan menggunakan pewarnaan Hematoksilin \& Eosin (HE) di Sekolah Tinggi Universitas Jenderal Achmad Yani (STIKES AYANI), Cimahi. Preparat histologi yang diperoleh dilihat dibawah mikroskop perbesaran 400x.

\subsubsection{Analisis Data}

Analisis statistika dilakukan menggunakan metode statistik ANOVA dilanjutkan post hoc LSD dengan bantuan perangkat lunak IBM SPSS Statistics 20. Perbedaan yang signifikan ditandai dengan nilai $\mathrm{p}<0,05$.

\section{Hasil}


Tanaman pecut kuda (Stachytarpheta jamaicensis (L.) Vahl) yang diperoleh merupakan tanaman pecut kuda yang termasuk kedalam keluarga Verbenaceae. Daun pecut kuda yang digunakan memiliki karakteristik morfologi daun dengan bentuk bulat telur, pangkal menyempit, ujung meruncing, tepi menyempit, berwarna hijau tua dan berbau khas. Hasil pemeriksaan karakteristik simplisia dapat dilihat pada Tabel 1.

Penapisan fitokimia dilakukan untuk menentukan kandungan metabolit sekunder yang terkandung dalam simplisia dan ekstrak air daun pecut kuda, dimana kandungan metabolit sekunder tersebut diduga memiliki aktivitas farmakologi pada tubuh manusia. Berdasarkan hasil penapisan fitokimia menunjukan bahwa pada simplisia dan ekstrak air daun pecut kuda mengandung senyawa metabolit sekunder seperti flavonoid, polifenol, tanin, kuinon, saponin, steroid, monoterpen dan seskuiterpen. ${ }^{11}$

Pengujian efek penggunaan ekstrak air daun pecut kuda dilakukan secara in vivo pada hewan mencit putih jantan galur Balb/c yang diinduksi oleh imiquimod (salep Aldara) untuk membuat model hewan mirip dengan kondisi psoriasis. ${ }^{12}$ Kondisi psoriasis yang ditandai dengan timbulnya plak dan kemerahan pada bagian punggung serta telinga. ${ }^{13}$ Tingkat keparahan psoriasis terus meningkat pada kelompok 2 hingga pengamatan di hari ke-15. Pada kelompok normal hanya menandakan kondisi kulit normal hingga terjadi pertumbuhan bulu pada punggung. Pengamatan dilakukan setiap hari selama lima belas hari melalui pengamatan secara visual oleh tiga pengamat. Hasil pengamatan dapat dilihat pada Gambar 1.
Pengamatan pertumbuhan plak, kemerahan pada kulit punggung, kemerahan pada telinga dan perhitungan nilai PASI dapat dilihat pada Gambar 2.

Selama pemberian sediaan pembanding metotreksat dan ekstrak air daun pecut kuda yang dimulai pada hari ketujuh hingga hari kelima belas, menunjukan penurunan angka pertumbuhan plak dan kemerahan yang diikuti dengan pertumbuhan bulu pada bagian punggung hewan. Pada hewan normal, pertumbuhan bulu mulai terjadi pada hari kedua atau ketiga setelah dilakukan pencukuran bulu. Hal tersebut menunjukan bahwa sediaan metotreksat dan ekstrak air daun pecut kuda telah memberikan aktivitasnya terhadap model hewan psoriasis. Pemberian ekstrak uji dosis pada semua dosis mengakibatkan penurunan yang cukup signifikan $(p<0.05)$ jika dibandingkan dengan kelompok kontrol dan pembanding yang menunjukan bahwa ekstrak air daun pecut kuda memiliki khasiat untuk menurunkan kondisi pada hewan psoriasis.

Selanjutnya dilakukan pemeriksaan histopatologi untuk melihat jumlah keratinosit pada epidermis yang diinduksi dengan imiquimod. Pemberian imiquimod dapat mengakibatkan terjadinya peningkatan jumlah keratinosit pada bagian epidermis sehingga terjadi peningkatan ketebalan dan pertumbuhan plak pada kulit. Berdasarkan hasil histopatologi yang dapat dilihat pada Gambar 3, dan perhitungan ketebalan keratin pada kulit punggung dan telinga dapat dilihat pada Tabel 2.

Pemberian sediaan pembanding dan ekstrak air daun pecut kuda dapat menurunkan jumlah keratinosit pada bagian epidermis jika dibandingkan kelompok kontrol. Pada

Tabel 1. Data hasil pemeriksaan karakteristik simplisia daun pecut kuda

\begin{tabular}{clcc}
\hline No & Pemeriksaan Karakteristik & Hasil (\%) & Persyaratan (\%) $^{\mathbf{1 0}}$ \\
\hline 1 & Kadar Air $(\% \mathrm{v} / \mathrm{b})$ & $3,53 \pm 0,503$ & $\leq 10$ \\
2 & Kadar Abu Total $(\% \mathrm{~b} / \mathrm{b})$ & $7,12 \pm 0,399$ & $\leq 16$ \\
3 & Kadar Abu Larut Air $(\% \mathrm{~b} / \mathrm{b})$ & $2,93 \pm 0,548$ & - \\
4 & Kadar Abu Tak Larut Asam (\%b/b) & $1,93 \pm 0,621$ & $\leq 4$ \\
5 & Kadar Sari Larut Air $(\% \mathrm{~b} / \mathrm{b})$ & $25,03 \pm 1,55$ & $\geq 16$ \\
6 & Kadar Sari Larut Etanol $(\% \mathrm{~b} / \mathrm{b})$ & $21,1 \pm 1,562$ & $\geq 14$ \\
\hline
\end{tabular}


Normal

Kontrol

Metotreksat

$0,2 \mathrm{mg} / \mathrm{kg}$ BB

Ekstrak Air Daun Pecut Kuda Dosis $25 \mathrm{mg} / \mathrm{kg}$ BB

Ekstrak Air Daun Pecut Kuda Dosis $50 \mathrm{mg} / \mathrm{kg} \mathrm{BB}$

Ekstrak Air Daun Pecut Kuda Dosis $100 \mathrm{mg} / \mathrm{kg} \mathrm{BB}$

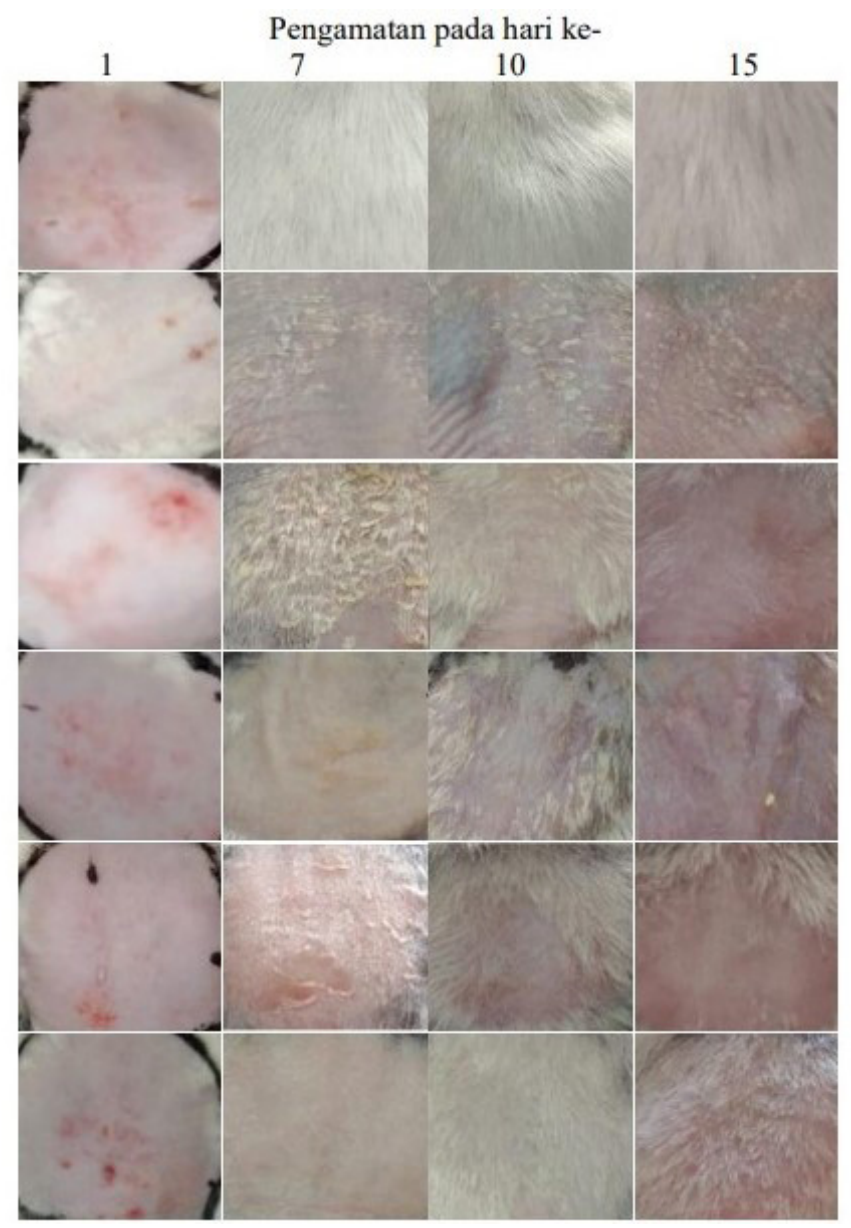

Gambar 1. Hasil pengamatan kulit punggung selama pengujian pada semua kelompok uji. Pengamatan hari ke-1 (sebelum induksi), hari ke-7 (6 hari setelah induksi), hari ke-10 (9 hari setelah induksi dan 3 hari setelah pemberian sediaan uji) dan hari ke-15 (14 hari setelah induksi dan 8 hari setelah pemberian sediaan uji)

ekstrak uji dosis 25 dan $50 \mathrm{mg} / \mathrm{kgBB}$ terjadi bahwa aktivitas pada ekstrak uji dosis 100 penurunan keratinosit pada bagian epidermis $\mathrm{mg} / \mathrm{kgBB}$ memberikan efek samping yang punggung dan telinga kanan jika dibandingkan berlebih berupa terjadinya peningkatan dengan kelompok kontrol dan pembanding. jumlah keratinosit.

Sedangkan, pada ekstrak uji dosis $100 \mathrm{mg} /$ $\mathrm{kgBB}$, peningkatan jumlah keratinosit masih terjadi bahkan melebihi jumlah keratinosit

\section{Pembahasan}

Psoriasis merupakan penyakit inflamasi pada kelompok kontrol. Hal ini menunjukan kronis pada kulit yang ditandai dengan

Tabel 2. Data hasil pemeriksaan karakteristik simplisia daun pecut kuda

\begin{tabular}{lcc}
\hline \multirow{2}{*}{ Kelompok } & \multicolumn{2}{c}{ Tebal Keratin (nm) } \\
\cline { 2 - 3 } & Kulit punggung & Telinga \\
\hline Normal & $17,285 \pm 1,818$ & $13,922 \pm 0,385$ \\
Kontrol & $26,263 \pm 3,585$ & $19,869 \pm 4,585$ \\
Metotreksat $0,2 \mathrm{mg} / \mathrm{kg} \mathrm{BB}$ & $24,331 \pm 2,500$ & $16,418 \pm 1,085$ \\
Ekstrak Air Daun Pecut Kuda 25 mg/kg BB & $22,840 \pm 2,254$ & $15,193 \pm 1,486$ \\
Ekstrak Air Daun Pecut Kuda 50 mg/kg BB & $27,123 \pm 2,021$ & $7,702 \pm 0,107$ \\
Ekstrak Air Daun Pecut Kuda 100 mg/kg BB & $31,444 \pm 18,275$ & $8,528 \pm 1,018$ \\
\hline $\mathrm{n}=3$ & &
\end{tabular}



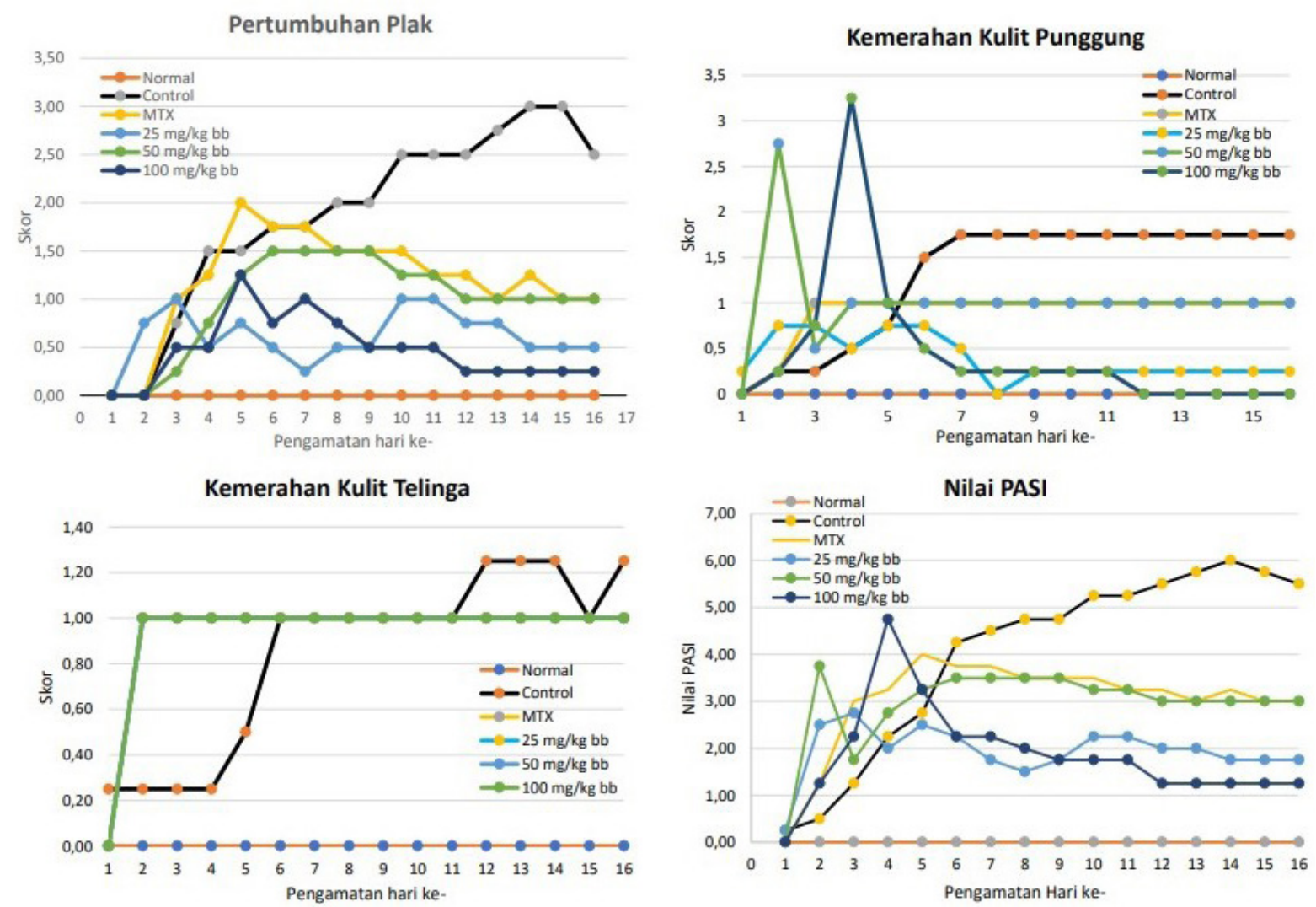

Gambar 2. Evaluasi skor PASI terhadap kondisi hewan model psoriasis selama pengujian
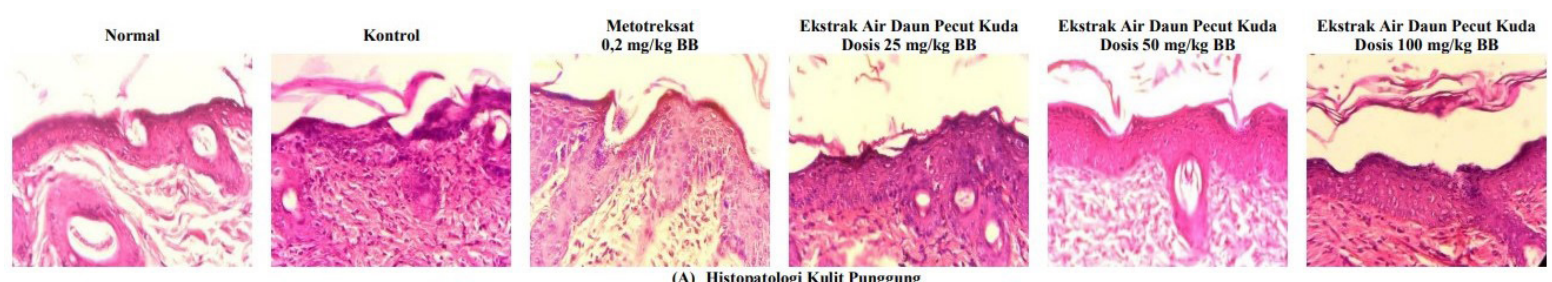

(A) Histopatologi Kulit Punggung
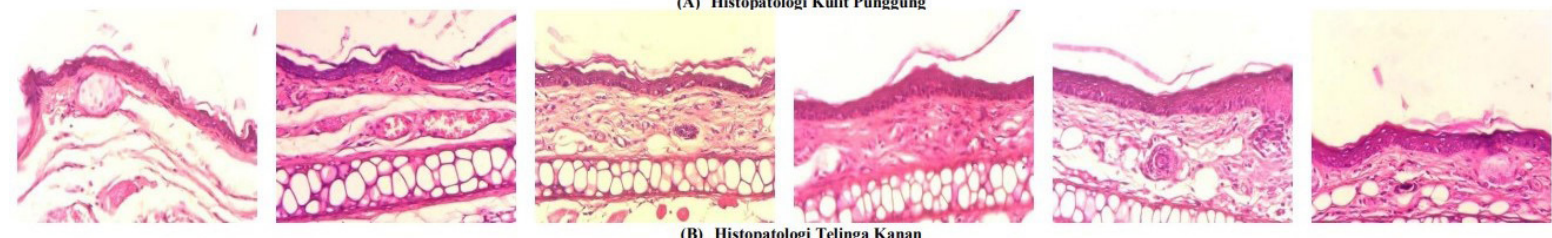

Gambar 3. Hasil pemeriksaan histopatologi dengan pewarnaan Hematoksilin \& Eosin (HE) pada epidermis kulit punggung (A) dan telinga kanan (B); a: keratin

hiperproliferasi keratinosit akibat sel $\mathrm{T}$ yang teraktivasi oleh antigen-presenting cell (APC). Sel $\mathrm{T}$ yang teraktivasi akan menstimulasi mediator proinflamasi yang bekerja pada keratinosit sehingga memicu peradangan pada bagian dermis. ${ }^{14}$ Hal tersebut menunjukan bahwa pengobatan psoriasis mengarah terhadap penggunaan obat yang bersifat antiinflamasi. Obat pilihan utama untuk mengobati psoriasis tipe plak yaitu metotreksat. ${ }^{15}$ Metotreksat merupakan salah satu obat golongan antagonis asam folat steroid yang bersifat antiinflamasi. Penggunaan metotreksat pada penderita psoriasis dapat menurunkan produksi mediator proinflamasi dan regulasi sel $T$ sehingga obat ini dapat digunakan untuk mengatasi inflamasi. Dalam kondisi psoriasis, metotreksatjuga menunjukan aktivitas sebagai agen imunomodulator dan antimetabolit. ${ }^{16}$

Tanaman pecut kuda memiliki aktivitas sebagai imunomodulator yang 
berperan sebagai agen imunosupresan. ${ }^{11}$ Efek imunomodulator tersebut dapat bekerja secara spesifik dan non spesifik dan aktivitas ini terdapat pada tanaman pecut kuda yang dapat mempengaruhi sistem imun humoral dan selular. ${ }^{17}$ Tanaman pecut kuda juga diketahui memiliki aktivitas sebagai antiinflamasi dengan efek samping yang lebih kecil jika dibandingkan penggunaan obat antiinflamasi nonsteroid. Aktivitas ini bekerja terhadap model hewan dengan peradangan akut dan kronis yang memungkinkan terjadinya penghambatan pada siklooksigenase. ${ }^{6}$

Aktivitas antiinflamasi yang dihasilkan dari tanaman diduga berasal dari kandungan metabolit sekunder flavonoid. ${ }^{18}$ Berdasarkan hasil penapisan fitokimia, daun pecut kuda memiliki kandungan metabolit sekunder berupa senyawa flavonoid dan steroid. Flavonoid bekerja pada siklooksigenase dan produksi mediator proinflamasi. Flavonoid dari golongan flavonol, flavon dan isoflavon telah terbukti potensial sebagai antiinflamasi. ${ }^{19}$ Inflamasi juga dapat diobati dengan pemberian obat steroid. Kortikosteroid digunakan untuk mengobati inflamasi dan imunosupresan, sehingga obat ini jika digunakan jangka panjang dapat mengakibatkan efek yang merugikan. ${ }^{20}$

Dari patogenesis psoriasis yang menunjukan keterlibatan agen proinflamasi dan sistem imun, mengakibatkan pengobatan dapat dilakukan dengan obat yang berkhasiat antiinflamasi. Untuk menghindari efek samping yang merugikan, penggunaan ekstrak air daun pecut kuda dapat dilakukan sebagai obat alternatif yang lebih aman untuk digunakan jangka panjang. Toksisitas ekstrak air tanaman pecut kuda lebih besar dari 5.000 $\mathrm{mg} / \mathrm{kgBB}$ sehingga keamanannya termasuk kategori senyawa yang praktis tidak toksik. ${ }^{21}$ Pemberian ekstrak air daun pecut kuda pada dosis $100 \mathrm{mg} / \mathrm{kgBB}$ dapat mengakibatkan efek samping sehingga perlu dilakukan pengujian lebih lanjut berupa uji toksisitas subkronik.

Ekstrak air daun pecut kuda telah terbukti dapat menunjukan aktivitasnya dalam menekan keparahan psoriasis melalui agen antiinflamasi dan imunosupresan. Jika dibandingkan dengan pengobatan tradisional Tiongkok, pemberian ekstrak air daun pecut kuda memiliki biaya pengobatan jangka panjang yang lebih ringan dan aktivitas yang lebih aman pada dosis tertentu. ${ }^{4}$ Pemberian dosis tinggi secara berulang dapat menyebabkan reaksi merugikan.

\section{Simpulan}

Ekstrak air daun pecut kuda pada semua dosis memiliki aktivitas untuk menekan keparahan pada saat kekambuhan psoriasis dengan dosis paling efektif untuk menekan kondisi psoriasis berada pada rentang dosis 25 dan $50 \mathrm{mg} / \mathrm{kgBB}$.

\section{Ucapan Terima kasih}

Ucapkan terima kasih kepada Ditjen Belmawa yang telah memberikan dana penelitian melalui program PKM-RE tahun 2021 serta semua pihak di Universitas Jenderal Achmad Yani yang membantu terlaksananya penelitian ini.

\section{Pustaka}

1. World Health Organization. Global report on Psoriasis. WHO Libr Cat Publ Data. 2016.

2. Kamiya K, Kishimoto M, Sugai J, Komine M, Ohtsuki M. Risk Factors for the Development of Psoriasis. Int J Mol Sci. 2019; 20(18):4347.

3. Rendon A, Schakel K. Psoriasis Pathogenesis and Treatment. Int $\mathrm{J}$ Mol Sci. 2019; 20(6):1475.

4. Meng S, Lin Z, Wang Y, Wang Z, Li P, Zheng Y. Psoriasis therapy by Chinese medicine and modern agents. Chinese Med (United Kingdom) [Internet]. 2018;13(1):1-10. Available from: https:// doi.org/10.1186/s13020-018-0174-0.

5. Dalimartha dr. S. Atlas Tumbuhan Obat Indonesia Jilid 2. In Jakarta: Trubus Agriwiyata; 2008.

6. Liew PM, Yong YK. Stachytarpheta jamaicensis ( L .) Vahl : From Traditional Usage to Pharmacological Evidence. Evidence-Based Complement Altern Med. 2016; 2016:7842340.

7. Vikasari SN, Sutjiatmo AB, Sukandar 
EY, Suryani S, Setiadi A, Lestari RA. Effect of Water Extract of Stachytarpheta jamaicensis Herbs on Inflammatory and Hematological Profile on Animal Induced Pristane. Japanese Pharmacol Soc. 2018; 755(1):012010.

8. Kementrian Kesehatan Republik Indonesia. Farmakope Indonesia Herbal edisi II. II. RI KK, editor. Jakarta: Katalog dalam Terbitan, Kementerian Kesehatan RI; 2017.

9. Depkes RI. Materia Medika Indonesia Jilid III. Direktorat Jenderal Pengawasan Obat dan Makanan; 1979.

10. Depkes RI. Parameter Standar Umum Ekstrak Tumbuhan Obat. cetakan pe. Jakarta: Departemen Kesehatan RI; 2000.

11. Vikasari SN, Soemardji A, Sutjiatmo AB. Immunomodulatory Effect of Water Extract of Stachytarpheta jamaicensis ( L .) Vahl. 2015;5(Suppl 2):62-6.

12. Rather IA, Bajpai VK, Han JH, Nam GJ. Imiquimod-induced psoriasis-like skin inflammation in mouse model. Bangladesh J Pharmacol. 2016;11(4):849-51.

13. Jabeen M, Boisgard AS, Danoy A, Kholti N El, Salvi JP, Boulieu R, et al. Advanced characterization of imiquimodinduced psoriasis-like mouse model. Pharmaceutics. 2020;12(9):1-18.

14. Frank O. Nestle, M.D., Daniel H. Kaplan, M.D., Ph.D., Jonathan Barker MD. Mecanism of disease Psoriasis. Th e new Engl J o f Med. 2009; 361:496-509.

15. Gudjonsson J, Elder J. Psoriasis. McGraw-Hill. 2012.

16. Law JH, Koo B, Koo JYM. Methotrexate Update: Mechanism of Action in Psoriasis Therapy. Psoriasis Forum. 2008; $14 \mathrm{a}(1): 17-28$.

17. Vikasari SN, Wahyuningsih S, Sutjiatmo AB. Specific Immunomodulatory Effect of Water Extract of Stachytarpheta jamaicensis herbs Specific Immunomodulatory Effect of Water Extract of Stachytarpheta jamaicensis herbs. 2021;8-13.

18. Ramadhani N, Sumiwi SA. Aktivitas Antiinflamasi Berbagai Tanaman Diduga Berasal Dari Flavonoid. Farmaka.
2013;14(2):111-23.

19. Alfaridz F, Amalia R. Klasifikasi dan Aktivitas Farmakologi dari Senyawa Aktif Flavonoid. Farmaka. 2018;16(3):19.

20. Dennis M Williams. Clinical Pharmacology of Corticosteroids. Respir Care. 2018;

21. Sutjiatmo AB, Sukandar EY, Vikasari SN. Uji Toksisitas Akut Ekstrak Air Herba Pecut Kuda (Stachytarpheta Jamaicensis (L) Vahl) pada Mencit Swiss Webster. 2015;3(2):32-7. 